\title{
Molybdenum Recovery from Filters Used in Large-scale Dissolution of Sintered Mo-disks
}

Chemical \& Fuel Cycle Technologies Division 


\begin{abstract}
About Argonne National Laboratory
Argonne is a U.S. Department of Energy laboratory managed by UChicago Argonne, LLC under contract DE-AC02-06CH11357. The Laboratory's main facility is outside Chicago, at 9700 South Cass Avenue, Lemont, Illinois 60439. For information about Argonne and its pioneering science and technology programs, see www.anl.gov.
\end{abstract}

\title{
DOCUMENT AVAILABILITY
}

Online Access: U.S. Department of Energy (DOE) reports produced after 1991 and a growing number of pre-1991 documents are available free at OSTI.GOV (http://www.osti.gov/),

a service of the US Dept. of Energy's Office of Scientific and Technical Information.

Reports not in digital format may be purchased by the public from the National Technical Information Service (NTIS):

U.S. Department of Commerce

National Technical Information Service

5301 Shawnee Road

Alexandria, VA 22312

www.ntis.gov

Phone: (800) 553-NTIS (6847) or (703) 605-6000

Fax: (703) 605-6900

Email: orders@ntis.gov

Reports not in digital format are available to DOE and DOE contractors from the Office of Scientific and Technical Information (OSTI):

U.S. Department of Energy

Office of Scientific and Technical Information

P.O. Box 62

Oak Ridge, TN 37831-0062

www.osti.gov

Phone: (865) 576-8401

Fax: (865) 576-5728

Email: reports@osti.gov

\section{Disclaimer}

This report was prepared as an account of work sponsored by an agency of the United States Government. Neither the United States Government nor any agency thereof, nor UChicago Argonne, LLC, nor any of their employees or officers, makes any warranty, express or implied, or assumes any legal liability or responsibility for the accuracy, completeness, or usefulness of any information, apparatus, product, or process disclosed, or represents that its use would not infringe privately owned rights. Reference herein to any specific commercial product, process, or service by trade name, trademark, manufacturer, or otherwise, does not necessarily constitute or imply its endorsement, recommendation, or favoring by the United States Government or any agency thereof. The views and opinions of document authors expressed herein do not necessarily state or reflect those of the United States Government or any agency thereof, Argonne National Laboratory, or UChicago Argonne, LLC. 
ANL-21/04

\section{Molybdenum Recovery from Filters Used in Large-scale Dissolution of Sintered Mo-disks}

by

David J Bettinardi and Peter Tkac

Chemical \& Fuel Cycle Technologies Division, Argonne National Laboratory

January 2021 



\section{CONTENTS}

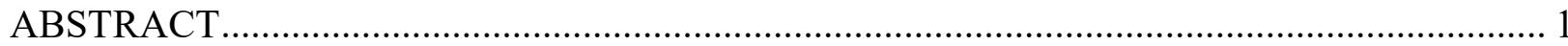

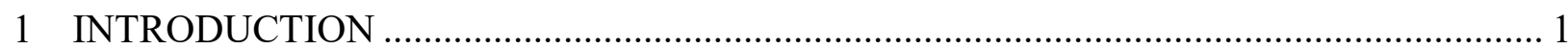

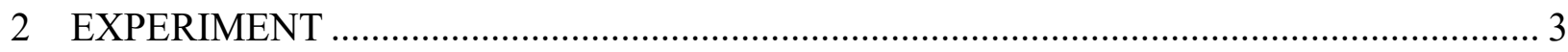

3 RESULTS

3.1 SartoPure PP3 MidiCap Filters .............................................................................. 5

3.2 GE Whatman Polycap TC Filters ........................................................................ 8

3.3 Recovery from Dried Whatman Filters ............................................................. 10

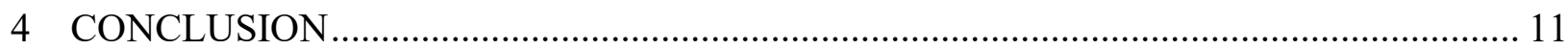

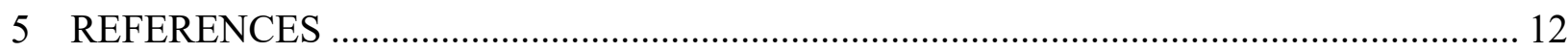

\section{FIGURES}

1 Filtration assembly showing feed bottle, filter unit, and effluent bottle............................ 4

2 Effluent solution showing a pale yellow color. ........................................................ 5

3 Sartorius filter after filtration, showing significant residual solution remaining in the housing even when the filter is in an upright position............................................. 5

4 Washing profile of Mo collected from Sartorius filter after filtration of $2.6 \mathrm{M}$ $\mathrm{K}_{2} \mathrm{MoO}_{4}$ followed by consecutive $50 \mathrm{~mL}$ washes of $5 \mathrm{M} \mathrm{KOH}$ solution. Solution drained from the filter housing and the subsequent dried filter were also measured after the wash steps to confirm Mo removal................................................................... 7

5 Washing profile of Mo collected from Whatman filter after filtration of $2.6 \mathrm{M}$ $\mathrm{K}_{2} \mathrm{MoO}_{4}$ followed by consecutive $50 \mathrm{~mL}$ washes of $5 \mathrm{M} \mathrm{KOH}$ solution. The filter was measured after wash steps to confirm Mo removal. 


\section{TABLES}

1 Mo recoveries from Sartorius filter measured by ${ }^{99}$ Mo activity with counting error ( $\mu \mathrm{Ci} \pm$ err) in feed, effluent, and filter after filtration.

2 Mo recoveries from Sartorius filter measured by ${ }^{99}$ Mo activity with counting error ( $\mu \mathrm{Ci} \pm$ err) in feed, effluent, and filter after filtration and $100 \mathrm{~mL}$ wash. .....

3 Mo recoveries from Whatman filter measured by ${ }^{99} \mathrm{Mo}$ activity with counting error ( $\mu \mathrm{Ci} \pm$ err) in feed, effluent, wash, and filter after filtration and $\mathrm{H}_{2} \mathrm{O}$ wash. 8

4 ICP-MS data for Mo and Fe recoveries from two dried Whatman filters used during real dissolution of sintered Mo disks. Filters were washed 5 times with a $5 \mathrm{M} \mathrm{KOH}$ solution 


\begin{abstract}
${ }^{99}$ Mo production with linear accelerators can be achieved via the bremsstrahlung photonuclear reaction ${ }^{100} \mathrm{Mo}(\gamma, \mathrm{n}){ }^{99} \mathrm{Mo}$ or the neutron capture reaction ${ }^{98} \mathrm{Mo}(\mathrm{n}, \gamma){ }^{99} \mathrm{Mo}$. For commercial producers, maximum recovery of enriched ${ }^{98} \mathrm{Mo}$ and ${ }^{100} \mathrm{Mo}$ target material is critical for sustaining an economic production cycle. During the peroxide dissolution of Mo metal disks and subsequent conversion to $\mathrm{K}_{2} \mathrm{MoO}_{4}$, several grams of Mo can be lost during filtration from solution when several hundred grams of sintered Mo disks are processed. This investigation shows that $5-8 \mathrm{~g}$ Mo is routinely retained on the filter units, but it can be almost fully recovered using aqueous washes. Washing can be done immediately and incorporated into the dissolution procedure, or it can occur several months after the initial filtration process to decrease processing time.
\end{abstract}

\title{
1 INTRODUCTION
}

The radionuclide ${ }^{99 \mathrm{~m}} \mathrm{Tc}$ ( $6.01 \mathrm{hr}$ half-life) is used in approximately $80 \%$ of all nuclear medicine procedures performed worldwide [1]. Commercial production of its parent nuclide ${ }^{99} \mathrm{Mo}$ (66 h half-life), which is traditionally harvested from ${ }^{235} \mathrm{U}$ fission, has recently branched into alternative production routes using natural or enriched Mo metal targets [2]. Linear accelerator based ${ }^{99}$ Mo production can then be achieved via either the bremsstrahlung photonuclear reaction ${ }^{100} \mathrm{Mo}(\gamma, \mathrm{n}){ }^{99} \mathrm{Mo}$ or the neutron capture reaction ${ }^{98} \mathrm{Mo}(\mathrm{n}, \gamma){ }^{99} \mathrm{Mo}$. In either case, the high cost of enriched Mo material (\$500-\$1000/g for $\mathrm{kg}$ quantities) means that efficient recovery and recycling strategies for Mo are crucial to the development of the technology.

The RadioGenix generator that NorthStar developed to produce ${ }^{99 \mathrm{~m}} \mathrm{Tc}$ from low-specificactivity ${ }^{99} \mathrm{Mo}$ uses dissolved $\mathrm{K}_{2} \mathrm{MoO}_{4} / \mathrm{KOH}$ as its source. The full dissolution and conversion of large $600 \mathrm{~g}$ batches of Mo metal disks to $\mathrm{K}_{2} \mathrm{MoO}_{4}$ can take approximately 2-3 hours to complete. The process begins shortly after irradiation, when Mo metal targets are placed in a hot cell for dissolution by hydrogen peroxide and conversion to potassium molybdate by an equimolar quantity of $\mathrm{KOH}[3]$ :

$$
\begin{gathered}
2 \mathrm{Mo}(\mathrm{s})+10 \mathrm{H}_{2} \mathrm{O}_{2} \rightarrow\left[\mathrm{Mo}_{2} \mathrm{O}_{3}\left(\mathrm{O}_{2}\right)_{4}\left(\mathrm{H}_{2} \mathrm{O}\right)_{2}\right]^{2-}+2 \mathrm{H}_{3} \mathrm{O}^{+}+5 \mathrm{H}_{2} \mathrm{O} \\
{\left[\mathrm{Mo}_{2} \mathrm{O}_{3}\left(\mathrm{O}_{2}\right)_{4}\left(\mathrm{H}_{2} \mathrm{O}\right)_{2}\right]^{2-}+8 \mathrm{KOH} \rightarrow 4 \mathrm{~K}_{2} \mathrm{MoO}_{4} \cdot\left(\mathrm{H}_{2} \mathrm{O}\right)_{2}+5 \mathrm{O}_{2}}
\end{gathered}
$$

Both reactions are strongly exothermic and vigorous, producing heat, $\mathrm{O}_{2}$, and bubbles. The result is a slightly alkaline, pale yellow solution containing approximately $0.2 \mathrm{~g} / \mathrm{mL}$ of Mo ( 2 M Mo).

After dissolution, the solution volume is reduced by evaporation via continuous heating to increase Mo concentration and destroy unreacted peroxide. Once the partial evaporation of the 
solution is complete, and the solution is cooled, a small amount of $1 \mathrm{M} \mathrm{Fe}\left(\mathrm{NO}_{3}\right)_{3}$ solution is added to induce coprecipitation of the trace metal contaminants $\mathrm{Nb}$ and $\mathrm{Zr}$, which are produced as byproducts during irradiation along with $\mathrm{Fe}(\mathrm{III})$. This solution must be filtered before the Mo product solution is adjusted to $5 \mathrm{M} \mathrm{KOH}$. It was observed that measurable losses of Mo in the filter unit can occur during this filtration.

The purpose of this investigation is to assess Mo losses in two types of filters that are used in the full-scale process and to develop efficient Mo recovery strategies. Tc retention and recoveries were also monitored and reported. 


\section{EXPERIMENT}

Solutions of 2.0-2.6 $\mathrm{M} \mathrm{K}_{2} \mathrm{MoO}_{4}$ (pH 8.99-9.25) were prepared either by dissolution of $\mathrm{K}_{2} \mathrm{MoO}_{4}$ in $\mathrm{H}_{2} \mathrm{O}$ or dissolution of $\mathrm{MoO}_{3}$ into a $\mathrm{KOH}$ solution $(\mathrm{pH} \sim 10)$. $\mathrm{MoO}_{3} / \mathrm{KOH}$ dissolution is exothermic, so $\mathrm{MoO}_{3}$ was added slowly in small portions as the temperature of the solution reached $45^{\circ} \mathrm{C}-55^{\circ} \mathrm{C}$ following the reaction:

$$
\mathrm{MoO}_{3}+2 \mathrm{KOH} \rightarrow 2 \mathrm{~K}^{+}+\mathrm{MoO}_{4}{ }^{2-}+\mathrm{H}_{2} \mathrm{O}
$$

Stock $\mathrm{K}_{2} \mathrm{MoO}_{4}$ solutions were divided into $500 \mathrm{~mL}$ aliquots for experiments. To each aliquot, $5 \mathrm{~mL}$ of $1 \mathrm{M} \mathrm{Fe}\left(\mathrm{NO}_{3}\right)_{3}$ solution was added (i.e., $5 \mathrm{~mL} \mathrm{Fe}\left(\mathrm{NO}_{3}\right)_{3}$ per $500 \mathrm{~mL} 2.6 \mathrm{M} \mathrm{Mo}$ ). Filtration of $500 \mathrm{~mL}$ feed solutions represent a $\sim 1 / 5$ batch of $600 \mathrm{~g}$ Mo disk dissolution $(\sim 2.4 \mathrm{~L})$. Solutions were spiked with a ${ }^{99}$ Mo radiotracer to determine Mo recovery yields.

Filtration and recovery characteristics were studied on two filters used in Mo disk processing:

1) Sartorius SartoPure PP3 MidiCap Filters (Cat\# 5055306P7--SS, Lot\# 005005503) Materials: polypropylene (housing), polypropylene fleece (filter), silicone (O-rings); pore size: $0.45 \mu \mathrm{m}$; max allowable pressure: $72.5 \mathrm{psi}$ at $20^{\circ} \mathrm{C}$.

2) GE Whatman Polycap TC 36mm dia. Filters (Cat\# 6714-3604, Lot\# 16995055) Materials: polypropylene (housing), polyethersulfone membrane (filter); pore size: $0.6 / 0.45 \mu \mathrm{m}$; max allowable pressure: $60 \mathrm{psi}$ at $20^{\circ} \mathrm{C}$.

The assembly in Figure 1 shows the Sartorius filter placed in a vertical orientation to minimize loss of solution in the filter housing after filtration. Filtration was done under vacuum using a Welch self-cleaning dry vacuum at 400-600 torr. Filters were not wetted prior to use. After filtration, the filters were measured for ${ }^{99} \mathrm{Mo}$ activity (wet or dry/drained) to analyze the Mo fraction retained by the filter. In the experiments followed in this report, wash solutions comprising 0-18 M KOH were used to recover Mo from the filters.

Unless otherwise stated, the valves located on individual filter units (vent valve and runoff valve on Sartorious filters, vent valve on Whatman filters) were kept in the closed position to simulate the ideal hot cell operating procedure. In trials where solution is drained through the run-off valve, a short length of tubing was used to connect the valve to the effluent bottle. 


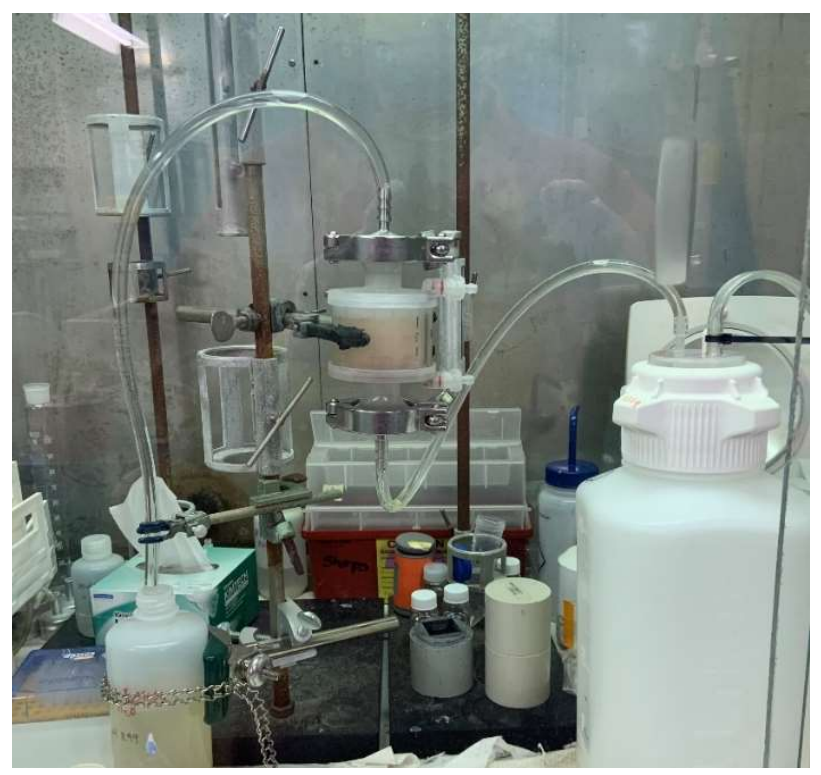

FIGURE 1 Filtration assembly showing feed bottle (left bottom), filter unit (center), and effluent bottle (right).

Bottle and sample vial masses were recorded when necessary. Small losses of liquid solution, occurring as droplets in tubing or bottles after solution transfer, were minimized by reducing the tube length and container size. $5 \mathrm{~mL}$ samples of feed, effluent, and washes were taken by micropipette and transferred to $20 \mathrm{~mL}$ vials for gamma counting.

Sample activities were measured on an ORTEC high-purity germanium (HPGe) detector. Samples were measured at $25 \mathrm{~cm}$ or $50 \mathrm{~cm}$ using the $739.5 \mathrm{keV}$ gamma energy peak for ${ }^{99} \mathrm{Mo}$. Filters were counted at $50 \mathrm{~cm}$, and no geometry correction was made for the results listed in Tables 1-3.

Samples for ICP-MS were analyzed using a PerkinElmer NexION 2000 ICP-MS spectrometer. The instrument was calibrated with reference samples prepared by diluting the National Institute of Standards and Technology (NIST) traceable standard solutions procured from Ultra Scientific (North Kingstown, Rhode Island, USA). 


\section{RESULTS}

Complete separation of Fe precipitate from the $\mathrm{K}_{2} \mathrm{MoO}_{4}$ solutions was achieved using both filters. The collected effluent solutions were a clear yellowish color (Figure 2) identical to solutions obtained during large-scale Mo disk dissolutions. Total filtration time for each feed solution varied by filter, taking either $\sim 30$ seconds (Whatman) or $\sim 5$ min (Sartorius) for complete filtration. Corresponding solution flow rates ranged from $1 \mathrm{~L} / \mathrm{min}$ (Whatman) to $0.1 \mathrm{~L} / \mathrm{min}$ (Sartorius).

\subsection{SartoPure PP3 MidiCap Filters}

Figure 3 shows the Sartorius filter after filtration, where liquid Mo solution remains trapped in the filter housing. Vacuum-pulled air from the feed solution bottle flows through the top of the cylindrical filter past the trapped solution and does not fully drain the solution. Since solution is poorly recovered using blown air, aqueous washes were used to recover the remaining solution. Alternatively, manipulation of the run-off valve can drain the trapped solution but will also drain Fe precipitate.

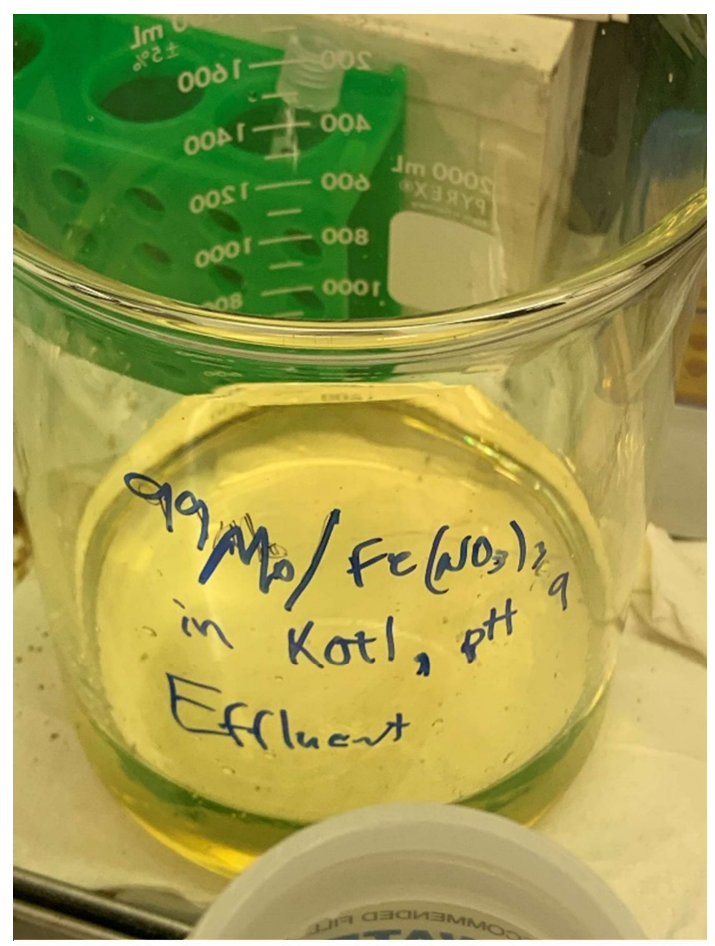

FIGURE 2 Effluent solution showing a pale yellow color.

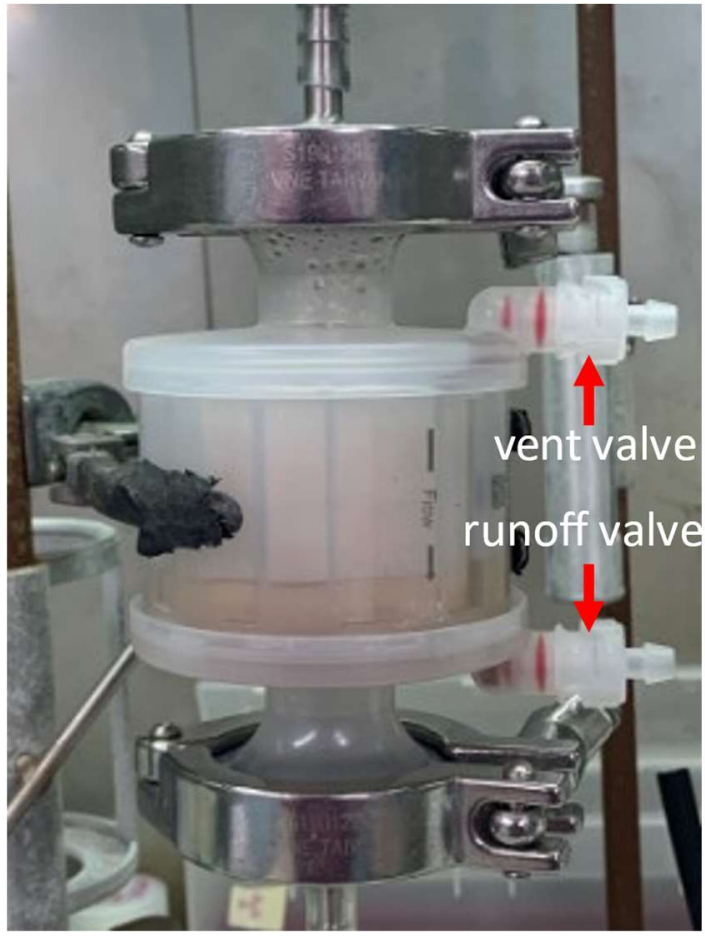

FIGURE 3 Sartorius filter after filtration, showing significant residual solution remaining in the housing even when the filter is in an upright position. 
Table 1 shows the results of the baseline trial measuring solution mass and activity of Mo remaining on the filter when no wash is added to the filter. Approximately $38 \mathrm{~g}$ of Mo solution (including Fe precipitate) remains in the filter. More significantly, 6.5\% of the total Mo from the feed solution is trapped in the filter, and this represents a slightly higher Mo concentration $\left(0.28 \mu \mathrm{Ci}{ }^{99} \mathrm{Mo} / \mathrm{g}\right.$ solution $)$ than that of both feed $(0.24 \mu \mathrm{Ci} / \mathrm{g})$ and effluent $(0.25 \mu \mathrm{Ci} / \mathrm{g})$ solutions. This indicates that Mo may be weakly sorbed to the Fe precipitate or on the polypropylene membrane.

TABLE 1 Mo recoveries from Sartorius filter measured by ${ }^{99} \mathrm{Mo}$ activity with counting error $(\mu \mathrm{Ci} \pm$ err) in feed, effluent, and filter after filtration.

\begin{tabular}{lrrrrrc}
\hline & & $\begin{array}{c}\text { Solution } \\
\text { Mass (g) }\end{array}$ & $\begin{array}{c}\text { Total }{ }^{99} \text { Mo Activity } \\
(\mu \mathrm{Ci} \pm \text { err })\end{array}$ & $\begin{array}{c}\text { Mo } \\
(\%)\end{array}$ & $\begin{array}{c}{ }^{99} \text { Mo Concentration } \\
(\mu \mathrm{Ci} / \mathrm{g} \text { Solution })\end{array}$ & $\begin{array}{c}\text { Mo Mass } \\
(\mathrm{g})\end{array}$ \\
\hline \multirow{2}{*}{ Trial 1: } & Feed & 695 & $168.1 \pm 5.51$ & $100 \%$ & 0.24 & 125 \\
No Wash & Effluent & 636 & $162.20 \pm 5.38$ & $96.5 \%$ & 0.25 & 121 \\
& Filter & 38.3 & $10.9 \pm 0.36$ & $6.5 \%$ & 0.28 & 8.1 \\
\hline
\end{tabular}

The results of washing experiments are shown in Table 2. Mo losses are reduced to about $1 \%$ after the filter is washed with $100 \mathrm{~mL}$ of either $\mathrm{H}_{2} \mathrm{O}$ or $5 \mathrm{M} \mathrm{KOH}$ solution. The activity per mass of solution dropped by a factor of 3.5 in both trials, which is consistent with the dilution of $\sim 20 \mathrm{~mL}$ solution with $100 \mathrm{~mL}$ of wash solution. It can therefore be assumed that the wash solution and the trapped solution containing Mo mix in the filter housing before exiting the filter.

TABLE 2 Mo recoveries from Sartorius filter measured by ${ }^{99} \mathrm{Mo}$ activity with counting error $(\mu \mathrm{Ci} \pm$ err) in feed, effluent, and filter after filtration and $100 \mathrm{~mL}$ wash.

\begin{tabular}{lrccccc}
\hline & & $\begin{array}{c}\text { Total }{ }^{99} \mathrm{Mo} \\
\text { Activity }(\mu \mathrm{Ci} \pm \text { err })\end{array}$ & $\begin{array}{c}{ }^{99} \mathrm{Mo} \\
(\%)\end{array}$ & $\begin{array}{c}{ }^{99 \mathrm{~m}} \mathrm{Tc} \\
(\%)\end{array}$ & $\begin{array}{c}{ }^{99} \mathrm{Mo} \text { Concentration } \\
(\mu \mathrm{Ci} / \mathrm{g} \text { Solution })\end{array}$ & $\begin{array}{c}\text { Mo Mass } \\
(\mathrm{g})\end{array}$ \\
\hline Trial 2: & Feed & $258 \pm 10.1$ & $100 \%$ & $100 \%$ & 0.37 & 125 \\
H2O Wash & Effluent + Wash & $252 \pm 10.0$ & $97.5 \%$ & $97.8 \%$ & 0.39 & 122 \\
& Filter & $2.8 \pm 0.1$ & $1.1 \%$ & $1.0 \%$ & 0.11 & 1.3 \\
$\begin{array}{l}\text { Trial 3: 5 } \\
\text { M KOH }\end{array}$ & Feed & $507 \pm 18.3$ & $100 \%$ & $100 \%$ & 0.71 & 125 \\
Wash & Effluent + Wash & $492 \pm 18.1$ & $97.1 \%$ & $97.5 \%$ & 0.74 & 121 \\
\hline
\end{tabular}


Based on the above results, and due to the small variation in Mo species chemistry between $\mathrm{pH} 8$ and 14, it is likely that any molar concentration of $\mathrm{KOH}$ will yield recoveries similar to those seen in Trials 2 and 3 . The composition of the wash solution can therefore be adjusted to meet the requirements of the final effluent concentrations. For example, $18 \mathrm{M} \mathrm{KOH}$ solution may be added directly into the evaporation vessel after filtration to wash both the evaporation vessel and the filter unit while simultaneously adjusting the final solution to $5 \mathrm{M}$ $\mathrm{KOH}$.

After the baseline trial, the washing profiles of consecutive $50 \mathrm{~mL}$ washes of $\mathrm{KOH}$ solution were examined. The results are shown in Figure 4. Washing was followed by a manual drain of the remaining solution in the filter through the runoff valve. The remaining ${ }^{99}$ Mo activity was measured in the filter after draining to determine total Mo losses on the filter surface. As in the previous trials, a total of about $8 \mathrm{~g}$ of Mo remains on the filter after filtration. After the first and second washes (100 mL combined volume), Mo content in the filter was reduced to $1-1.5 \mathrm{~g}$ $(1 \%)$ Mo. After 5 wash steps $(250 \mathrm{~mL})$ the Mo losses were reduced to roughly $300 \mathrm{mg}(<<1 \%)$. Holdup volume in the filter housing remains constant throughout filtration and washing steps so the observed results are reflective of Mo dilution in the original solution.

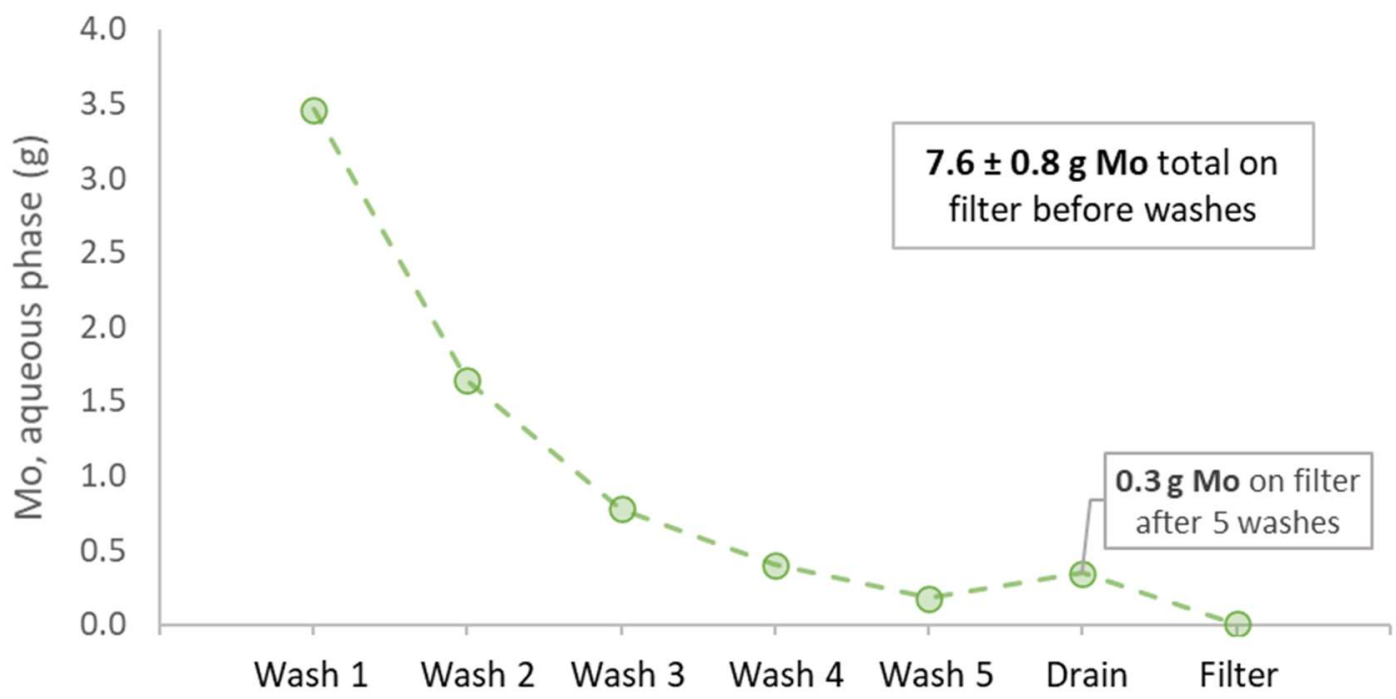

FIGURE 4 Washing profile of Mo collected from Sartorius filter after filtration of $2.6 \mathrm{M} \mathrm{K}_{2} \mathrm{MoO}_{4}$ followed by consecutive $50 \mathrm{~mL}$ washes of $5 \mathrm{M} \mathrm{KOH}$ solution. Solution drained from the filter housing (via the runoff valve) and the subsequent dried filter were also measured after the wash steps (last two points) to confirm Mo removal.

The drained solution containing Fe precipitate was sampled and counted for ${ }^{99} \mathrm{Mo}$ activity, showing that washing adequately removed $>99 \%$ of Mo. The dried filter was removed and counted, showing negligible activity after draining $(0.01 \mathrm{~g} \mathrm{Mo})$, confirming that nearly all Mo was successfully recovered. 
As an alternative recovery approach, draining the Mo solution directly through the runoff valve was also explored. The filter was tilted $45^{\circ}$ to allow complete drainage through the valve as the filter was washed with $2 \times 50 \mathrm{~mL}$ of $5 \mathrm{M} \mathrm{KOH}$. Surprisingly, Mo was poorly recovered from the filter by simply draining the solution. Washes 1 and 2 recovered merely $0.38 \pm 0.05 \mathrm{~g}$ Mo and $0.04 \pm 0.01 \mathrm{~g} \mathrm{Mo,} \mathrm{respectively,} \mathrm{indicating} \mathrm{that} \mathrm{Mo} \mathrm{may} \mathrm{in} \mathrm{fact} \mathrm{be} \mathrm{adsorbed} \mathrm{to} \mathrm{the}$ polypropylene membrane instead of dissolved in solution as previously thought.

\subsection{GE Whatman Polycap TC Filters}

Three similar trials were performed to recover Mo from Whatman filters using different wash solutions $(0-18 \mathrm{M} \mathrm{KOH})$. The results shown in Table 3 indicate that $96.7 \pm 1.1 \%$ of Mo passes through the filter while about $4 \mathrm{~g}(3 \%)$ Mo remains trapped on the filter. After washing the filter with $100 \mathrm{~mL}$ of solution, Mo losses were reduced to $1-1.6 \mathrm{~g} \mathrm{(1 \% )} \mathrm{Mo,} \mathrm{showing} \mathrm{results}$ similar to those of the Sartorius filter. The efficiency of Mo recovery did not vary significantly between the 0 and $18 \mathrm{M} \mathrm{KOH}$ wash solution compositions.

Interestingly, Tc retention in the Whatman filter was markedly higher than that in the Sartorius filters. About $10 \%-15 \%$ of the total Tc content remained on the filter across all trials, even after washing with $0-18 \mathrm{M} \mathrm{KOH}$. This finding points to polyethersulfone membranes as the most likely cause of ${ }^{99 \mathrm{~m}} \mathrm{Tc}$ retention.

TABLE 3 Mo recoveries from Whatman filter measured by ${ }^{99}$ Mo activity with counting error $\left(\mu \mathrm{Ci} \pm\right.$ err) in feed, effluent, wash, and filter after filtration and $\mathrm{H}_{2} \mathrm{O}$ wash.

\begin{tabular}{|c|c|c|c|c|c|c|}
\hline & & $\begin{array}{l}\text { Total }{ }^{99} \mathrm{Mo} \\
\text { Activity }(\mu \mathrm{Ci} \\
\pm \text { err })\end{array}$ & $\begin{array}{l}{ }^{99} \mathrm{Mo} \\
(\%)\end{array}$ & $\begin{array}{l}{ }^{99 \mathrm{~m}} \mathrm{Tc} \\
(\%)\end{array}$ & $\begin{array}{c}{ }^{99} \mathrm{Mo} \\
\text { Concentration } \\
(\mu \mathrm{Ci} / \mathrm{g} \text { Solution })\end{array}$ & $\begin{array}{c}\text { Mo } \\
\text { Mass } \\
\text { (g) }\end{array}$ \\
\hline \multirow{4}{*}{$\begin{array}{l}\text { Trial 1: } \mathrm{H}_{2} \mathrm{O} \\
\text { Wash }\end{array}$} & Feed & $714 \pm 27$ & $100 \%$ & $100 \%$ & 1.16 & 125 \\
\hline & Effluent & $691 \pm 27$ & $96.8 \%$ & $85.6 \%$ & 1.15 & 121 \\
\hline & $\mathrm{H}_{2} \mathrm{O}$ Wash & $14 \pm 0.6$ & $1.8 \%$ & $2.2 \%$ & 0.14 & 2.3 \\
\hline & Filter & $11 \pm 0.4$ & $1.3 \%$ & $11.2 \%$ & 0.71 & 1.6 \\
\hline \multirow{4}{*}{$\begin{array}{l}\text { Trial 2: } \\
5 \text { M KOH } \\
\text { Wash }\end{array}$} & Feed & $713 \pm 29$ & $100 \%$ & $100 \%$ & 1.20 & 125 \\
\hline & Effluent & $677 \pm 26$ & $95.2 \%$ & $82.8 \%$ & 1.22 & 119 \\
\hline & $5 \mathrm{M} \mathrm{KOH}$ Wash & $28 \pm 1.2$ & $3.6 \%$ & $3.8 \%$ & 0.23 & 4.5 \\
\hline & Filter & $9.6 \pm 0.4$ & $1.2 \%$ & $13.4 \%$ & 0.43 & 1.5 \\
\hline \multirow{4}{*}{$\begin{array}{l}\text { Trial 3: } \\
18 \text { M KOH } \\
\text { Wash }\end{array}$} & Feed & $713 \pm 29$ & $100 \%$ & $100 \%$ & 1.20 & 125 \\
\hline & Effluent & $677 \pm 26$ & $95.2 \%$ & $82.8 \%$ & 1.22 & 119 \\
\hline & $18 \mathrm{M} \mathrm{KOH}$ Wash & $28 \pm 1.2$ & $3.6 \%$ & $3.8 \%$ & 0.23 & 4.5 \\
\hline & Filter & $9.6 \pm 0.4$ & $1.2 \%$ & $13.4 \%$ & 0.43 & 1.5 \\
\hline
\end{tabular}


A washing profile was collected for the Whatman filter and is shown in Figure 5. Mo recovery from the filter after two washes (100 mL combined volume) totaled $4-5 \mathrm{~g}(4 \%)$. After 6 wash steps $(300 \mathrm{~mL})$, Mo losses were reduced to $400 \mathrm{mg}(<1 \%)$, equating to near-total $(>99 \%)$ recovery of Mo from the filter. The small fraction $(440 \mathrm{mg})$ of Mo that does not wash from the filter may be trapped on the outside edges of the membrane, which are difficult to wash properly at constant flow and may require further soaking.

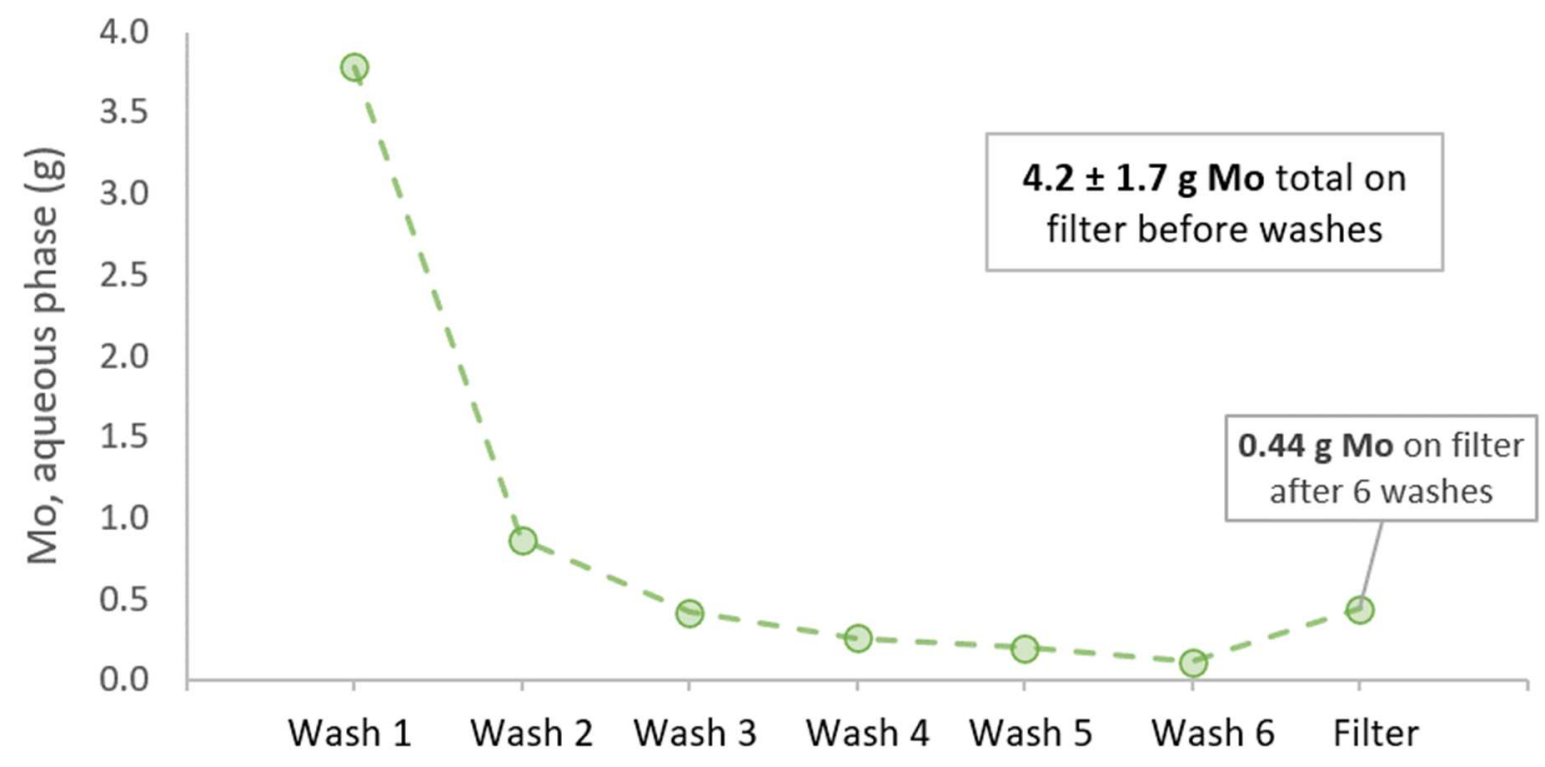

FIGURE 5 Washing profile of Mo collected from Whatman filter after filtration of $2.6 \mathrm{M}$ $\mathrm{K}_{2} \mathrm{MoO}_{4}$ followed by consecutive $50 \mathrm{~mL}$ washes of $5 \mathrm{M} \mathrm{KOH}$ solution. The filter was measured after wash steps (last point) to confirm Mo removal.

Based on these results, $\mathrm{KOH}$ solution may be directly added to the dissolution or evaporation apparatus and used to wash the filter while simultaneously functioning to adjust the final solution to the desired $5 \mathrm{M} \mathrm{KOH}$. However, this step may only be viable if the redissolution of $\mathrm{Nb}$ or $\mathrm{Zr}$ from the $\mathrm{Fe}$ (III) precipitate is prevented. $\mathrm{Nb}$ is known to form oxoanionic species in strongly alkaline solutions such as $\mathrm{Nb}_{6} \mathrm{O}_{19}{ }^{8-}$ and $\mathrm{H}_{\mathrm{x}} \mathrm{Nb}_{6} \mathrm{O}_{19}{ }^{(8-\mathrm{x})-}$ ( $\mathrm{pH}$ 11-14.5) and could therefore begin to redissolve during $\mathrm{KOH}$ washes, although this was not investigated in this study [5]. Alternatively, washing with a weaker $\mathrm{KOH}$ solution $(\sim \mathrm{pH} 9)$ may avoid the dissolution of $\mathrm{Nb} / \mathrm{Zr}$, but it will require longer evaporation times to achieve the same $\mathrm{K}_{2} \mathrm{MoO}_{4}$ concentration in the final solution, which will have been diluted by the washes. Due to the possible removal of $\mathrm{Zr}$ and $\mathrm{Nb}$ when a highly alkaline $\mathrm{KOH}$ solution is used to wash the filter, the most practical way to recover Mo from the filters may be to wash the filters well after the dissolution procedure is complete. 


\subsection{Recovery from Dried Whatman Filters}

An effort was made to test Mo recoveries from dried Whatman filters used during largescale dissolution processes at Argonne [4]. The wash process developed in this report was used on filters that had been left to dry for 6-9 months. Both filters had been used for Fe-precipitate filtration during large-batch Mo disk dissolutions of $451.6 \mathrm{~g}$ Mo (Filter 1) and $365.1 \mathrm{~g} \mathrm{Mo}$ (Filter 2) disks. Dissolved Mo batches were larger and therefore contained more Fe precipitate, which was captured in the filters. $22 \mathrm{~mL}$ and $18.3 \mathrm{~mL}$ of $1 \mathrm{M} \mathrm{Fe}\left(\mathrm{NO}_{3}\right)_{3}$ were used with filter 1 and filter 2 , respectively. Therefore, each filter contained considerably more Fe-precipitate $(\sim 4 \times)$ than those used in small-scale experimental trials. Fe breakthrough was examined in addition to Mo recoveries to determine whether redissolution occurred during washes.

Results for Mo and Fe content of wash solutions are presented in Table 4. The results show that Fe remained undissolved and was not detected in any of the $\mathrm{KOH}$ washes. The wash profiles of both filters show a gradual tapering off of Mo recoveries and suggest that nearly all Mo is recovered from the filters by wash 5. Filter 1 contained roughly $1.3 \mathrm{~g} \mathrm{Mo}(0.3 \%)$ while Filter 2 contained about $4.7 \mathrm{~g}(1.3 \%)$ Mo in total. Although these values represent a small percentage of the total Mo per batch, the near-complete recovery of several-gram quantities of enriched ${ }^{98 / 100}$ Mo from filters can be done very simply and economically.

TABLE 4 ICP-MS data for Mo and Fe recoveries from two dried Whatman filters used during real dissolution of sintered Mo disks. Filters were washed 5 times with a $5 \mathrm{M}$ KOH solution.

\begin{tabular}{lccccc}
\hline Sample & $\begin{array}{c}\text { Fe } \\
(\mathrm{g} / \mathrm{L})\end{array}$ & $\begin{array}{c}\text { Mo } \\
(\mathrm{g} / \mathrm{L})\end{array}$ & $\begin{array}{c}\text { Total Mo } \\
(\mathrm{g})\end{array}$ & $\begin{array}{c}\text { Mo } \\
\text { \% of Total from } \\
\text { Dissolution })\end{array}$ \\
\hline Blank & $5 \mathrm{M} \mathrm{KOH}$ & $<5.85 \times 10^{-2}$ & $<2.25 \times 10^{-3}$ & - & - \\
\hline Filter 1 & Wash 1 & $<5.85 \times 10^{-2}$ & 16.95 & 0.85 & $0.19 \%$ \\
& Wash 2 & $<5.85 \times 10^{-2}$ & 5.92 & 0.30 & $0.07 \%$ \\
& Wash 3 & $<5.85 \times 10^{-2}$ & 2.01 & 0.10 & $0.02 \%$ \\
& Wash 4 & $<5.85 \times 10^{-2}$ & 0.95 & 0.05 & $0.01 \%$ \\
& Wash 5 & $<5.85 \times 10^{-2}$ & 0.61 & 0.03 & $0.01 \%$ \\
& Total & $<5.85 \times 10^{-2}$ & - & 1.33 & $0.30 \%$ \\
\hline Filter 2 & Wash 1 & $<5.85 \times 10^{-2}$ & 61.30 & 3.07 & $0.84 \%$ \\
& Wash 2 & $<5.85 \times 10^{-2}$ & 16.55 & 0.83 & $0.23 \%$ \\
& Wash 3 & $<5.85 \times 10^{-2}$ & 8.02 & 0.40 & $0.11 \%$ \\
& Wash 4 & $<5.85 \times 10^{-2}$ & 4.48 & 0.22 & $0.06 \%$ \\
& Wash 5 & $<5.85 \times 10^{-2}$ & 3.32 & 0.17 & $0.05 \%$ \\
& Total & - & - & 4.69 & $1.29 \%$ \\
\hline
\end{tabular}




\section{CONCLUSION}

It was demonstrated that Mo can be recovered from filters used during large-scale dissolution of irradiated Mo targets using water or $\mathrm{KOH}$ washes. After the $\mathrm{K}_{2} \mathrm{MoO}_{4}$ solution is filtered, Mo retention in the filters was as high as $8 \mathrm{~g}$ Mo (SartoPure MidiCap Filters) and $5 \mathrm{~g}$ Mo (Whatman Polycap filters). Mo retention most likely stems from the weak physisorption of molybdate to filter membrane surfaces, allowing it to be easily recovered in alkaline washes even after several months of drying. Draining the solution from the filter housing through the runoff valve was not adequate to recover most of the Mo, indicating that the majority of Mo holdup is associated with the membrane and not the solution: Adequate washing of the membranes is required. Near-complete recovery of Mo from both filters can be obtained with 100-200 mL washes of $\mathrm{KOH}$ with no detectable Fe contamination occurring.

If it is convenient to hot cell operations, a sufficient volume of $\mathrm{KOH}$ solution may be directly added to the dissolution or evaporation apparatus and used to wash the filter while also functioning to adjust the final solution to the desired $5 \mathrm{M} \mathrm{KOH}$. However, it may be simpler to do filter washing in a procedure separate from the dissolution to avoid complications arising with the potentially increased solubility of $\mathrm{Nb}$ or Zr. Washing profiles collected from dried filters were nearly identical to those of freshly used filters, and no Fe breakthrough was detected in $5 \mathrm{M}$ $\mathrm{KOH}$ washes.

Interestingly, the polyethersulfone-based membrane (Whatman) exhibited notably different sorption properties for Tc than for Mo. Tc retention on the filter was roughly $10 \%-15 \%$ of total Tc content even after $\mathrm{KOH}$ washes. In contrast, the polypropylene membrane showed no evidence of strong chemical interaction with Mo or Tc. While the underlying reason for the Tc-sorption property of polyethersulfone is not clear, it could be of future interest when the partial removal of ${ }^{99 \mathrm{~g}} \mathrm{Tc}$ from ${ }^{99}$ Mo solutions is desired. 


\section{REFERENCES}

[1] National Academies of Sciences. Engineering, and Medicine, Molybdenum-99 for Medical Imaging. The National Academies Press: Washington, DC, 2016.

[2] International Atomic Energy Agency. Non-HEU Production Technologies for Molybdenum99 and Technetium-99m. Nuclear Energy Series No. NF-T-5.4; IAEA: Vienna, 2013.

[3] Peter Tkac, David Rotsch, Dominique Stepinski, Vakhtang Makarashvili, George Vandegrift, James Harvey, "Optimization of the Processing of Mo Disks," 2016. doi:10.2172/1240156.

[4] Peter Tkac, David A. Rotsch, Sergey D. Chemerisov, James P. Byrnes, James L. Bailey, Stanley G. Wiedmeyer, "Large-scale dissolution of sintered Mo disks," Journal of Radioanalytical and Nuclear Chemistry, 2021. doi:10.1007/s10967-020-07566-y.

[5] Montserrat Filella, Peter M. May, "The aqueous solution thermodynamics of niobium under conditions of environmental and biological interest," Applied Geochemistry (122), 2020. 


\section{Argonne}

\section{Chemical \& Fuel Cycle Technologies Division}

Argonne National Laboratory

9700 South Cass Avenue, BIdg. 205

Lemont, IL 60439-4832

www.anl.gov 